\title{
Harmfulness and Preventive Measures of Accounting Information Distortion \\ Qin Shanshan
}

\section{Shaanxi Vocational and Technical College of Finance and Economics, Xianyang, Shaanxi 712000 , China}

Key words: market economy; accounting information distortion; precautions

\begin{abstract}
In the environment of sustainable economic development, accounting information plays an important role in external decision-making, internal economic management and national macro-control, which is based on quality. Accounting information quality is the life of corporate accounting work. However, in recent years, the quality of accounting information has been declining, and its distortion is great, which has reached the level to be governed. Therefore, the author analyzes the actual situation of accounting information distortion in China, studies the causes of distortion, explores the strategies to solve the problem of accounting information distortion, and selects scientific prevention means to enhance the quality of accounting information and make it better serve the social and economic construction.
\end{abstract}

\section{Introduction}

At present, most of the audited units have a bad environment, which has a great impact on the image of the enterprises themselves and they also affect the normal economic order of socialism, affect the social status of listed companies, reduce investor enthusiasm and reduce information trust degree of information users. Corporate accounting information distortion is the current social concern. To change the situation, in line with China's economic development requirements, it is necessary to improve the external supervision and enhance the professional quality of accounting personnel and other aspects of the focus, put forward the accounting information distortion strategies and measures. And then let the accounting work for enterprise development and social and economic construction services, which is good to improve the legal system, maintaining social stability and harmony, and promote sustainable development of the market economy has a particularly important practical significance for China.

\section{The harmfulness caused by the distortion of enterprise accounting information}

At present, China's economy continues to develop rapidly, and in the process, it should avoid the 
phenomenon of accounting information distortion, because accounting information distortion will cause a series of economic market problems. First, the distortion of accounting information leads to the loss of state assets, and many lost assets will certainly affect the stability and security of state-owned assets, and even lead to a good situation in the economic market fall apart. Second, the accounting information distortion will appear uneven distribution of national income problemsand lead to the existing economic environment, improper trading problems. Therefore, the accounting information distortion will disrupt the normal economic order, thus hindering China's economic construction and development.

China's reform and opening policy makes the field of development vigorous. With the establishment and improvement of the system, the state has increased the importance of economic issues. The economic system is an important system of national progress and development, and the economy is the foundation of every link. Therefore, the economy is to promote the basic protection of national construction. The state comprehensively and systematically regulates the economic system and improves the adjustment of economic decision-making. Corporate information and data are particularly important for countries to formulate economic adjustment policies.If the accounting information distortion occurs, it will have a serious impact on the national economic decision-making, and reduce the role of decision-making. The state macro-control also will cause problems, such as weakening economic decision-making. Accounting information is difficult to effectively reflect the actual situation of China's social economy, it is difficult to objectively reflect the level of economic development, thus affecting macroeconomic decision-making, economic resource allocation and optimization system is facing contradictions.

Enterprise development is an important force to promote social and economic development, enterprise reform and economic reform are closely related. The accounting information distortion will affect the enterprise reform and trigger a lot of reform issues, limit or hinder the development of national enterprises. Enterprise accounting information has a particularly important role, such as property rights distribution, property assessment and state-owned enterprises to effectively improve the income, enterprises to clear property rights, assessment of assets, optimize the allocation of resources, different enterprises will be bankrupt, split, merger and so on.Accounting information reflects the authenticity of the characteristics of this feature consistent with the characteristics of state-owned enterprises. In addition, state-owned enterprise reform should also reflect the authenticity, and based on the real, perfect accounting information as reference data. If the accounting information is distorted, it will have an impact on the reform of the enterprise structure, and even allow the state-owned enterprises to face great economic losses. Therefore, the distortion 
of accounting information will undermine the economic system of state-owned enterprises, leading to state-owned enterprise reform and its economic system problems.

\section{The main reason leading to the distortion of accounting information}

The factors that lead to the distortion of accounting information include the imperfection of the accounting system, the internal governance structure of the enterprise and the lack of external supervision. It is mainly embodied in four aspects.

The accounting standards and accounting systems formulated and implemented by the state provide enterprises with alternative accounting methods and accounting principles and formulate the relevant "accounting system", but they have a certain distance from the international accounting standards, resulting in the lag in the implementation,which is one of the causes of accounting information distortion. Such as the use of accounting methods and change the accounting environment and the emergence of the synchronization, the actual accounting matters and the existence of accounting documents, such as the existence of the time difference will cause accounting information distortion; uncertain accounting information, to select the accounting method, the accounting principle will reduce the accuracy and authenticity of the accounting information; the state changes the financial regulations, tax system or enterprise misuse of accounting policies, regulations and accounting standards and other factors, resulting in accounting information is not true.

At present, China has a lot of new industries, new areas, new problems and new situations, not every accounting action can be found according to the "accounting standards", reflecting the current application of accounting theory in some areas difficult to meet the objective and comprehensive practice of economic business requirements. The accounting judgment of enterprise accounting has caused the accounting information to be distorted because of imperfect laws and regulations. When dealing with accounting illegality, it often uses the words "huge amount" and "serious circumstances". The standard of sentencing is lacking and the operability is weak.

Business accounting personnel lack of professional knowledge and sense of responsibility, professionalism and expertise of the business spirit, which is difficult for enterprises to provide accurate and true accounting information, reduce the authenticity of accounting information. Individual accounting personnel lack of basic professional ethics, with their duties to facilitate the implementation of illegal acts, through the destruction, concealment, forgery of accounting information and other methods, occupy private and state property; some accounting personnel lack of legal awareness and professional conduct, ignoring financial law, set up "small treasury", to do 
false account, false income, whitewash performance, leading to accounting information distortion.

In the practice of accounting work, there are false accounting, false financial statements, playing digital games and other phenomena, although the "new accounting law" proposed to strictly require accounting, but also the legal responsibility and consequences should be clearly defined, and the problem is just ordered the enterprise to pay a fine, part of the problem because of various relationships and human feelings, some business managers are contrary to the "new accounting law" and there are some problems, such as tax evasion, false profits, and false accounts.

\section{Measures to prevent accounting information distortion}

To prevent and solve the problem of accounting information distortion should be based on the source of information distortion as the starting point, from the external level and internal level proposed solutions. On the internal level, to build a sound and scientific enterprise system, establish and improve the accounting laws and regulations system; on external factors, to improve the supervision system, improve law enforcement efforts to protect enterprises in the legal system under the framework of operation. Therefore, it is an effective strategy to prevent and solve the problem of accounting information distortion, so it is important to construct the accounting honesty system and construct a strict and standardized supervision and management system, interest-oriented system and credit system.

It's necessary to clear accounting work, bear the legal responsibility, reverse the current stage of law, never to ignore the neglect of laws and regulations, through the authority to induce or force corporate accounting report and false accounting business leaders, not tolerate the provision of untrue, illegal accounting of the original vouchers or distortion accounting information of enterprise accounts staff. To fully implement and implement the "Accounting Law" and other accounting rules and regulations, has been checked out of the law, fraud, to increase the punishment of the relevant responsible person, increase the cost of accounting fraud, so that business leaders and accountants dare not try, hoping to prevent accounting fraud from the source.

Enterprises should constantly improve the internal audit system, inspection system, contain the system, and gradually realize self-control and self-restraint, effectively find and correct errors in error, fill the loopholes accurately, prevent corporate accounting fraud; pay more attention to the formulation and implementation of accounting management system, accounting management activities of the measures, means and systems to improve and standardize the enterprise responsible for accounting information authenticity and quality of the effective mechanism for business leaders, accounting staff, accounting institutions, managers and responsibilities of the division to improve 
the accounting staff management and supervision, to enhance the accuracy and authenticity of accounting information.

It's important to develop and abide by the enterprise, accounting personnel, intermediary units' integrity file system, pay attention to the role of publicity and accounting integrity, improve the accounting staff and business leaders of the integrity of awareness. Besides, education accounting staff should set up the basic moral principles of false accounts, and abide by the new system, to promote and improve the accounting professional ethics of the legalization and standardization of construction, to protect the accounting staff should have rights and interests, to establish a good environment against evil. The establishment and perfection of the honesty system can better enhance the professional ability and professional ethics level of accounting personnel.

The construction of a scientific and effective internal system should be carried out jointly with the internal audit department to carry out internal audit work, which can better enhance the quality of accounting information and comprehensively reflect the role of accounting supervision and control. To improve the authenticity and credibility of accounting information, regulate the behavior of intermediaries, through the management, inspection, supervision of intermediary practice level, improve industry self-discipline, with media to expose those intentional fraud, the lack of professional ethics, bad social impact of the illegal intermediaries, so that illegal disciplinary units are facing the most comprehensive social supervision, to a certain extent, it can reduce the reputation of the unit, let it accept the constraints of public opinion, and thus reflect the strong alert effect.

\section{Conclusion}

In short, in the current macroeconomic environment for sustainable development, we should continuously improve the supervision and management of enterprise accounting personnel, greatly enhance the quality and authenticity of accounting information, and then effectively protect the enterprise in the domestic and international market advantage. To attach importance to the legal system, improve the internal control system, establish accounting integrity system, attention to regulatory efforts to prevent accounting information distortion, and provide the necessary protection for the development of enterprises.

\section{References:}

[1] Duan Yong. Causes, Harms and Countermeasures of Accounting Information Distortion [J]. Modern Business, 2011,02: $219+218$. 
[2] JinXin.The Status Quo, Causes and Preventive measures of Accounting Information Distortion [J]. Contemporary economy, 2015,16: 56-57.

[3] Wang Hongyu. Analysis of Accounting Information Distortion of the Harm and Countermeasures [J]. Enterprise Herald, 2016, 03: 154-155. 